\title{
Varieties of Self-Realization: Art, Work, and the Self in Late Victorian England
}

\author{
PATRICK FESSENBECKER \\ Bilkent University
}

A wide body of scholarship agrees that the "aesthetic" writers of the late nineteenth century offered a new conception of the self that challenged Victorian norms and proclaimed a new theory of freedom. Murray Pittock for instance claims that Walter Pater "stresses the autonomy of the human spirit: that we create ourselves, and are the measure of our own value." Kate Hext expands this view, contending that Pater sees autonomy as a fragile achievement, a delicate structure constantly threatened by material conditions inside and outside oneself. ${ }^{2}$ Of course this connects to a rich philosophical literature on the unstable but perhaps therefore free identities of the flaneur and the "dandy"; as Len Gutkin puts it, the nineteenthcentury dandy was first and foremost "a figure of supreme autonomy." To mention one famous example of such scholarship, Michel Foucault departs from Charles Baudelaire's account of the "dandy"-who "makes of his body . . . a work of art"- to develop an account of the "aesthetics

In developing this argument I have had the welcome pleasure of receiving insights from a variety of different friends and readers. In addition to charitable and helpful reports from the two anonymous readers, I received valuable advice from many colleagues at the University of Southern Denmark, especially Bryan Yazell, Emily Hogg, Klaus Petersen, and the members of the Welfare State Studies reading group. Cory Stockwell's extensive knowledge of Gilles Deleuze and French poststructuralism saved the argument from veering off in an odd direction, and Marshall Brown's incisive and prompt commentary pointed toward an important restructuring. And finally I would like to thank the wonderful students in my class on "Work and the Meaning of Life" at Bilkent University - Gizem, Deniz, Berk, Ahmetcan, Utku, Uluğhan, and Büşra-whose reflections on Oscar Wilde and the self were the start of all this.

1. Murray Pittock, Spectrum of Decadence: The Literature of the 1890s (London: Routledge, 1993), 15-16.

2. Kate Hext, Walter Pater and Aesthetic Individualism (Edinburgh University Press, 2013). As she aptly puts it, "From his early identification of the 'problem of unity with ourselves' to his late assertion 'of the unity of the thing with itself,' he is perennially attempting to assuage Hume's negative thesis that 'I' is but a 'bundle or collection' of phenomena" (31).

3. Len Gutkin, Dandyism: Forming Fiction from Modernism to the Present (Charlottesville: University of Virginia Press, 2020), 2.

(C) 2020 by The University of Chicago. All rights reserved. 0026-8232/2020/11704-0005\$10.00 
of existence." ${ }^{4}$ And more recent research on women writers of the period has supplemented rather than refuted the view that new ideas about freedom and the self were central to the period's literature; Talia Schaffer has shown how women writers challenged masculine assumptions about the structure of the work of art and developed creative fusions of new and old forms of femininity. ${ }^{5}$ Admittedly, in regarding the aesthetes this way, such criticism reflects the writers' understanding of themselves, a point distilled well enough in Oscar Wilde's claim that "Art is the most intense mode of individualism that the world has known." 6

But we do not do a very good job of capturing the real philosophical stakes by taking such writers exactly at their word, by seeing them as the sole thinkers who acknowledged the mutability of the self and discovered the theory of freedom as self-creation. These were points many other and otherwise divergent thinkers were perfectly prepared to acknowledge and indeed to advocate themselves. When Wilde writes that "people whose desire is solely for self-realization never know where they are going," he is certainly offering an alternative to his contemporary F. H. Bradley, who asserts that the "self is realized in a whole of ends because it is a whole . . . this is what we mean by practical self-realization." ${ }^{7}$ Yet it is revealing of the subtlety of the differences between the two alternative views that both writers can see themselves as advocating "self-realization." Indeed, both are even prepared to admit an element of self-discovery in the process of selfrealization. F. H. Bradley insists that freedom requires integrating "the sensuous facts around us and in us," and that those who try to give their lives a clear pattern by ignoring or eliminating inconvenient desires deny our very humanity: "It is no human ideal to lead the life of an oyster." If we grant that "sensuous facts" inside oneself include sexual desires, it's easy to think that Wilde could understand the tension Bradley was considering and agree with his conclusion. Powerful social norms prohibiting the expression of certain desires might make it convenient to ignore or repress them,

4. Michel Foucault, "What Is Enlightenment?," in The Foucault Reader, ed. Paul Rabinow (New York: Pantheon Books, 1984), 41. Foucault turns to the broader account of the aesthetics of existence in the second and third volumes of the History of Sexuality; see esp. vol. 2, The Use of Pleasure, trans. Robert Hurley (New York: Pantheon, 1987).

5. I have in mind here Talia Schaffer and Kathy Alexis Psomiades, eds., Women and British Aestheticism (Charlottesville: University of Virginia Press, 1999), as well as Shaffer's The Forgotten Female Aesthetes: Literary Culture in Late-Victorian England (Charlottesville: University of Virginia Press, 2000), and Novel Craft: Victorian Domestic Handicraft and Nineteenth-Century Fiction (Oxford University Press, 2011). I shall return to Novel Craft in particular below.

6. Oscar Wilde, The Soul of Man under Socialism (London: Humphreys, 1900), 13.

7. Oscar Wilde, De Profundis, The Ballad of Reading Gaol, and Other Writings (Ware: Wordsworth, 1999), 23; F. H. Bradley, Ethical Studies, 2nd ed., rev. (Oxford: Clarendon, 1988), 67.

8. Bradley, Ethical Studies, 74. 
but as Wilde puts it in his famous 1897 letter to Lord Alfred Douglas, the acceptance of "all experiences," no matter how shameful, is an essential part of being an individual. ${ }^{9}$

Of course, not everyone is inclined to agree that there are sharp distinctions here. In a recent essay, Kit Andrews argues that Walter Pater for one shared the broadly Hegelian view that Bradley was defending, and that in fact Pater out-Hegeled his Oxford colleague T. H. Green: "In ways, though, Pater also goes beyond Green ... he reconstructs a variation on the thoroughgoing Hegelian logic of extremes that [Green's work] consistently resists." ${ }^{10}$ I argue that there is a deep and essential difference between the aesthetes and their neo-Hegelian rivals, and that we can get a better handle on the issues involved by looking at the topic of work. For perhaps the central fact about the dandy, the flaneur, and the aesthete is that they do not work, and an essential claim in the aestheticist theory of freedom is that it is precisely by refusing to work that aesthetes free themselves. As Philip Mann puts it in The Dandy at Dusk, "Owing to his identity as a work of art, the dandy is of necessity idle"; "his independence, assurance, originality, self-control, and refinement should all be visible in the cut of his clothes." 11 Conversely, to the neo-Hegelians and the older advocates of the Gospel of Work (I shall say more about the link between these two intellectual traditions in a moment), it was insofar as work offered the promise of autonomy that it seemed like an activity worth celebrating. So if we want to make sense

9. Although the letter was published in part in 1905 as "De Profundis," a number of scholars have argued the piece is better given the title Wilde himself gave it: "Epistola: In Carcere et Vinculis"; I shall follow them here, marking further citations to this work "Epistola" and including them parenthetically in the text. The piece only appeared in complete form in a 1962 edition of Wilde's letters; I here cite a selection of those letters in which the Douglas letter is included in full. See Selected Letters of Oscar Wilde, ed. Rupert Hart-Davis (Oxford University Press, 1979), 204. There is a wealth of scholarship on the scandal of Wilde's public homosexuality and the sequence of three trials that ended his career. For a brief but clear attempt to parse through the gossip surrounding the trials and their history, see Merlin Holland, "Oscar Wilde's Crime and Punishment: Fictions, Facts, and Questions," in Oscar Wilde in Context, ed. Kerry Powell and Peter Raby (Cambridge University Press, 2013). For a fuller treatment, see Michael S. Foldy, The Trials of Oscar Wilde: Deviance, Morality, and Late-Victorian Society (New Haven, CT: Yale University Press, 1997). For an argument that links the Wilde trials to other scandals of gay life in the late Victorian period, see Richard Dellamora, Masculine Desire: The Sexual Politics of Victorian Aestheticism (Chapel Hill: University of North Carolina Press, 1990).

10. Kit Andrews, "Walter Pater as Oxford Hegelian," Journal of the History of Ideas 72, no. 3 (2011): 448. My reaction here shares Benjamin Morgan's suspicion of a close link between Pater and Hegel in his "Aesthetic Freedom: Walter Pater and the Politics of Autonomy," ELH 77, no. 3 (Fall 2010): 731-56. Morgan presses on the relationship between autonomy and the aesthetic; a goal of this essay is to trace the additional and quite substantive difference between Pater's view and Hegel's conception of ethical and practical autonomy.

11. Philip Mann, The Dandy at Dusk: Taste and Melancholy in the Twentieth Century (London: Head of Zeus, 2018), introduction, Kindle. 
of why the aesthetes thought not working was a form of freedom, we need to look too at why their rivals thought it was. In so doing, what emerges first is that what is really in dispute is the relationship between purposive activity and self-unification. And second, this conceptual nexus highlights the insights in the art of William Morris, who reconceived work in a way that acknowledged the thrust of aestheticist intuitions about the self.

Before I begin, though, it's worth pausing to admit another point on which we benefit from not taking the aesthetes exactly at their word. For instance, one point Wilde is very clear on is that good art does not "say" anything, and that to engage a work of literature in terms of what it says is to violate its aesthetic nature. ${ }^{12}$ As a good deal of work in philosophical aesthetics has come to realize, Wilde is quite wrong here. Literature can and does say things all the time, and does so not in violation of the properties that make it interesting but instead in expression of them. ${ }^{13}$ Part of what I hope to show over the course of this essay is that Wilde's dictum is also misleading about his own work. His plays, stories, and essays have a number of interesting things to say, and collectively offer an intriguing theory of the self. To see this, however, we need to clarify somewhat the nature of the view of the self he was rejecting.

Thomas Carlyle proclaimed in 1843 that "The latest Gospel in this world is, Know thy work and do it." ${ }^{14}$ His remarks have rightly been taken by historians to epitomize one of the main threads of Victorian intellectual life; as developed by later writers like George Eliot and John Ruskin, the core notion here is that moral autonomy stems from the creation of an internal psychological structure. ${ }^{15}$ Moral agents begin life with a variety of desires,

12. As he puts it at one point, "Art never expresses anything but itself" ("The Critic as Artist," in Oscar Wilde: The Major Works, ed. Isobel Murray [Oxford University Press, 2008], 238; unless otherwise indicated, quotations from Wilde's works are taken from this edition). In a recent essay, Andrea Selleri has brought out the ways Wilde's philosophy of art were developed against a view he calls "authorialism," in which works of art were thought to directly express an author's views; see "Oscar Wilde on the Theory of the Author," Philosophy and Literature 42, no. 1 (April 2018): 49-66.

13. For an example of such scholarship, see Noël Carroll, Beyond Aesthetics (New York: Cambridge University Press, 2001). I discuss this problem in a 2013 essay and at greater length in a forthcoming book; see Patrick Fessenbecker, "In Defense of Paraphrase," New Literary History 44, no. 1 (Winter 2013): 117-39, and Reading Ideas in Victorian Literature: Literary Content as Artistic Experience (Edinburgh University Press, 2020).

14. Thomas Carlyle, Past and Present, ed. Chris R. Vanden Bossche, Joel J. Brattin, and D. J. Trela (Berkeley: University of California Press, 2006), § 3.11 .

15. See esp. Walter Houghton, The Victorian Frame of Mind, 1830-1870 (New Haven, CT: Yale University Press, 1957), 251. I have offered my own account with regard to Eliot in Patrick 
but the threat of internal disorder is countered by the agent's decision to regard one particular project as worthy for its own sake. This governing project forms the center of a psychological structure, affording coherence and therefore autonomy. ${ }^{16}$

Let me call the basic picture of the self underlying Carlyle's Gospel of Work the professional theory of agency. Stefan Collini has suggested that there was a sort of unreflective Kantianism to midcentury Victorian moral thought, and we see here another instance of that trend. ${ }^{17}$ As in Immanuel Kant's view, the professional account understands autonomy as inhering in the capacity of an agent to stand above a disordered mass of inclinations and act on the basis of intrinsically valuable goals..$^{18}$ It differs from Kant's view in two important ways. First, there is an essential element of selfdiscovery. The way an agent ought to decide what specific work to do was a point of dispute in Victorian thought, and a number of writers believed innate dispositions played a role in the process. Finding a career combined discovery of who one really was with the decision to turn oneself into something new. ${ }^{19}$ Second, in understanding action on the basis of disinterested reason as not the defining characteristic of moral action as such but as essentially linked to finding a particular concrete activity in the world, the vocational theory of agency makes moral autonomy dependent on social structures, particularly the organization of intrinsically valuable projects into lifestructuring careers.

In this second dimension, Victorian writers reflect a primary concern of one of Kant's major critics, G. W. F. Hegel. In his "empty formalism" objection, developed primarily in his 1820 work The Philosophy of Right, Hegel contends that Kant's theory of principled decision making via the categorical imperative was too abstract, and could never yield any actual content. ${ }^{20}$ As he puts it, "It is impossible to make the transition to the determination

Fessenbecker, "Sympathy, Vocation, and Moral Deliberation in George Eliot," ELH 85, no. 2 (Summer 2018): 501-32.

16. See Alan Mintz, George Eliot and the Novel of Vocation (Cambridge, MA: Harvard University Press, 1977), 66.

17. Stefan Collini, Public Moralists: Political Thought and Intellectual Life in Britain, 1850 1930 (Oxford: Clarendon, 1993), 63.

18. For a particularly clear explanation of Kant's view, see Christine M. Korsgaard, "Morality as Freedom," in Creating the Kingdom of Ends (New York: Cambridge University Press, 1996), 159-87.

19. See Jennifer Ruth, Novel Professions: Interested Disinterest and the Making of the Professional in the Victorian Novel (Columbus: Ohio State University Press, 2006), 3-5.

20. The primary source for this objection is G. W. F. Hegel, Elements of the Philosophy of Right, trans. H. B. Nisbet, ed. Allen W. Wood (Cambridge University Press, 1991), section 135. See Fabian Freyenhagen, "Empty, Useless, and Dangerous? Recent Kantian Replies to the Empty Formalism Objection," Bulletin of the Hegel Society of Great Britain 63 (2011): 163-86, for a review of recent scholarship on the objection and a sympathetic treatment of Hegel's point. 
of particular duties" when one conceived the moral law in Kantian terms as simply the requirement that one's maxims be free of contradiction. ${ }^{21}$ The fact that some principles of action could be willed as universal laws told one nothing about how to choose a particular principle to act on, and thus left moral agents without a way of deciding what they should actually do. What was needed was a more concrete way of realizing autonomy. Hegel found such a way in social structures that had survived and flourished in the process of historical evolution. The survival of such structures indicated that they embodied genuinely good reasons for existing, and so in fulfilling a particular place marked out by such a structure, individuals achieved the autonomy inherent in acting on the basis of selfless reasons.

Because of the affinity between Hegel's response to Kant and Victorian reflections on work, it's not surprising that the rise of neo-Hegelian idealism in the British universities in the 1870s saw a renewed version of the professional model of agency. In the hands of thinkers like Bradley and Green, work was the concrete realization of freedom. As Green puts it in his posthumous 1883 work Prolegomena to Ethics, the world of "distinctively human action" is one in which the causes of human actions are "motives," which he defines as "an idea of an end, which a self-conscious subject presents to itself, and which it strives and tends to realize." ${ }^{22}$ Thus, humans like animals have desires, but the nature of human consciousness changes their psychological operation. For Green and Bradley - as with Harry Frankfurt a century later - humans give themselves a shape by "identifying" with their desires. ${ }^{23}$ Because we have the ability to regard our inclinations, we similarly have the ability to situate our selves for or against any particular impulse. ${ }^{24}$ In Green's account of the process, "feelings and desires occur from moment to moment," passing without receiving a "reaction" from the "Ego." 25 In such cases, no real action on the part of the person occurs. But in other cases, "the Ego identifies itself with some desire, and sets itself to bring into real existence the ideal object." When the agent subsequently acts on such a desire, the action is free "not in the sense of being undetermined," but "in the sense that the motive lies in the man himself." ${ }^{26}$ To identify with

21. Hegel, Elements of the Philosophy of Right, 162.

22. T. H. Green, Prolegomena to Ethics, ed. A. C. Bradley (Oxford: Clarendon, 1906).

23. See Harry G. Frankfurt, The Importance of What We Care about: Philosophical Essays (New York: Cambridge University Press, 1998), 170-71.

24. As David O. Brink explains this view, "The self is not to be identified with any desire or any series or set of desires; moral personality consists in the ability to subject appetites and desires to a process of deliberative endorsement and to form new desires as the result of such deliberations" (Perfectionism and the Common Good: Themes in the Philosophy of T. H. Green [Oxford: Clarendon, 2003], 40).

25. Green, Prolegomena to Ethics, 115.

26. Ibid. 
a desire is to make it internal to oneself, and so action on its basis is free because autonomous, even though the initial feeling might be in some sense determined.

But we cannot achieve this process of identification by ourselves. Instead, as Bradley explains in his 1876 work Ethical Studies, the self is unified through the intersubjective process of according one's psychic elements with the concrete structures made possible by other people. Bradley's logic appears to be something like the following. Any attempt to give a structure created entirely by oneself to oneself risks arbitrariness: if the only reason a particular project is made central to one's life is one's own decision, then it is always possible to unmake the decision, and thus the self can never be fully unified, never entirely whole. Bradley explains that a man who gives himself a content "which falls wholly within himself" and "is not common to him with others" cannot produce any specific, concrete action, and thus we find ourselves pulled to the other extreme - that the content of our lives is determined entirely by others - to explain how agents come to produce actions. ${ }^{27}$ The ideal solution is dialectic, as agents subjectively recognize their own rationality made concrete in the reasons embodied in social structures.

This way of thinking is what leads Bradley and Green to their famously organicist views of self-realization. In a chapter aptly titled "My Station and Its Duties," Bradley argues, "The objective organism, the systematized moral world, is the reality of the moral will; my duties on the inside answer to due functions on the outside... I have to fill my place - the place that waits for me to fill it; to make my private self the means, my life the sphere and the function of the soul of the whole, which thus, personal in me, externalizes both itself and me into a solid reality." ${ }^{28}$ Put differently, people are only truly free of their private selves and therefore autonomous if they devote themselves to ends that are willed by the social organism. The needs of that collective structure create functions, and it is in devoting themselves to those ends that such agents give their lives nonarbitrary contents. When we will ourselves to pursue a set of ends valuable to the "objective organism"- a concrete and specific project that nevertheless serves the universal-we attain an internal coherence that permits each of us to become complete "wholes." Green's version is in some ways less rigid than Bradley's; he is concerned less that our freedom be concretely realized than that the functions one fills be linked to the common good. Nevertheless, he accepts the broad strokes of the answer: it is "only so far as we are members of a society, of which we conceive the common good as our own," Green admits, does the idea of the common good have "any practical 
hold on us at all, and this very membership implies confinement in our individual realization of the idea. Each has primarily to fulfill the duties of his station." ${ }^{29}$ We do not experience this form of freedom all the time, but it is an essential element in the phenomenology of the right kind of work; as Bradley writes, "In the moral man the consciousness of that unity [in himself and with society] can not be present always, but only when he is fully engaged in satisfactory work." 30

It is tempting to see the aestheticist self not as a rejection of the professional theory but as a variation on it. That's especially true because of the shared emphasis on disinterestedness in the two models: Walter Pater's emphasis on disinterested aesthetic experience looks, at first blush, like a version of the professional's unselfish commitment to an intrinsically valuable end. So it is not surprising that scholars like Jonathan Freedman see a link; as he asks rhetorically, "For what is the aesthete but the consummate professional?" 31 James Eli Adams agrees, writing that Pater's Marius the Epicurean is a "subtle articulation of the cultural logic that connects the professional and the priest." ${ }^{22}$ But despite these apparent links, I want to suggest that the aestheticist theory of the self should be understood in decisive opposition to the professional model of self-constitution.

To a significant extent, the aesthetes were first of all rejecting the implications about the moral force behind social norms. But they went a step further, or perhaps it is better to say that in rejecting the neo-Hegelian theory of normativity they found they had to offer an alternate theory of the distinctiveness of human agency and the structure of self-coherence. Accordingly, in his 1893 work Plato and Platonism, Pater considers Plato's view that individuals are born with functions and that their good consists in realizing those functions, explaining, "That Plato should exaggerate this definiteness in men's natural vocations, thus to be read as it were in 'plain figures' upon each, is one of the necessities of his position.... The counterassertion of the natural indifference of men, their pliability to circumstance, while it is certainly truer to our modern experience, is also in itself more hopeful, more congruous with all the natural process of education." ${ }^{33}$

29. Green, Prolegomena to Ethics, 209.

30. Bradley, Ethical Studies, 203. Bradley continues with the corollary: "When he is not so engaged, and the bad self shows itself, he can scarcely be self-contented."

31. Jonathan Freedman, Professions of Taste: Henry James, British Aestheticism, and Commodity Culture (Stanford University Press, 1990), xix.

32. James Eli Adams, Dandies and Desert Saints: Styles of Victorian Manhood (Ithaca, NY: Cornell University Press, 1995), 192.

33. Walter Pater, Plato and Platonism: A Series of Lectures (London, 1893), 217. 
Initially, the point here is to reject the idea of a fundamentally unalterable human nature. But Pater means more than this, since the rejection of vocation and the reference to our "pliability to circumstances" suggests a broader skepticism about the kind of definitive structuring Bradley and Green have in mind. Pater is explicit about this elsewhere; his 1873 work The Renaissance concludes, "It is with this movement, with the passage and dissolution of impressions, images, sensations, that analysis leaves offthat continual vanishing away, that strange, perpetual, weaving and unweaving of ourselves." 34

Against the view that selfhood consists in the capacity for autonomous agency and is constituted through a core project, Pater's alternative sees the self as simply a capacity for experience. In Marius the Epicurean, written in 1885, Pater represents this capacity as the source for a nonprofessional account of self-mastery. Marius begins the novel as a young man in search of something to do with his life, a position much like that of other famous Victorian protagonists, Moreover, he is well disposed to realize the kind of vocation encouraged by Eliot and Carlyle. Pater tells us that an early religious impulse "made him anticipate all his life long, as a thing towards which he must carefully train himself, some great occasion of self-devotion ... that should consecrate his life." 35 But he does not find such a project. Instead, he encounters the liberating possibilities of skepticism, which creates a "perpetual, inexhaustible thirst after experience" (57). Correspondingly, Marius rejects the idea of tailoring his means to some set of ends: "In the actual dimness of ways from means to ends, he would at all events be sure that the means ... should have something of finality or perfection about them" (62). Ultimately Marius sees "Life as the end of life"-positing the experience of living as the purpose of living - and seeks to focus his nature not around a project but around a capacity, turning his nature into "one complex medium of reception" (60). And when he does finally set to work, it is the kind of work that will free him from ever having to define himself. He decides to become a rhetorician, but his goal is to understand "the various forms of actual human feeling ... and in turn become the interpreter of them to others" (ix). In other words, so far from having to identify with one feeling and reject another, he takes up a position that requires him precisely to avoid this kind of discrimination, understanding all feelings as they are.

34. Walter Pater, The Renaissance: Studies in Art and Poetry (Cambridge University Press, 2011), 153-54. I take this claim to be largely in agreement with the scholarly consensus; see Angela Leighton, On Form: Poetry, Aestheticism, and the Legacy of a Word (Oxford University Press, 2007), 91.

35. Walter Pater, Marius the Epicurean: His Sensations and Ideas (New York: Cosimo Classics, 2005), 1. The quotations in the remainder of this paragraph are taken from this source, with page numbers given parenthetically. 
Oscar Wilde develops this view in a series of insightful ways. He fully shares Pater's rejection of the moral psychology underlying the professional theory, a fact that gives rise to much of his humor. For instance, his 1891 story "Lord Arthur Savile's Crime" parodies the idea of a vocation: when a fortune teller tells Lord Arthur that he will commit a murder, he experiences it as a selfless calling. Wilde observes, "He had to choose between living for himself and living for others, and terrible though the task laid upon him undoubtedly was, yet he knew he must not suffer selfishness to triumph over love." ${ }^{36}$ Similarly, The Importance of Being Earmest (1895) creates much of its effect through Lady Bracknell's parodically intense commitment to the Gospel of Work. When Jack Worthing admits that he smokes, for instance, Lady Bracknell approves because "a man should always have an occupation of some kind." ${ }^{37}$ And again, when Algernon Moncrieff decides to get rid of his fictional friend Bunbury by telling Lady Bracknell that he has died, her reaction is one of approval:

Algernon. $\quad$ My dear Aunt Augusta, I mean he was found out! The doctors found that Bunbury could not live, that is what I mean-so Bunbury died.

LADY BRACKNELL. He seems to have great confidence in the opinion of his physicians. I am glad, however, that he made up his mind at the last to some definite course of action, and acted under proper medical advice. ${ }^{38}$

Needless to say, murder, smoking, and dying are not the sort of clear lifeorganizing and agency-constituting projects Carlyle, Eliot, or Bradley have in mind.

Less ironically, a rejection of the Gospel of Work underlies Wilde's social criticism. As he argues in his 1891 essay The Soul of Man under Socialism, "There is nothing necessarily dignified about manual labor, and most of it is absolutely degrading. It is mentally and morally injurious to man to do anything in which he does not find pleasure." It is essential, he stresses, that the work be free: "Every man must be left quite free to choose his own work. No form of compulsion must be exercised over him." "We live in the age of the over-worked," ${ }^{40}$ Wilde writes to similar purpose in "The Critic as Artist," and in "Epistola: In Carcere et Vinculis" he borrows Pater's endsmeans objection. "The more mechanical people," Wilde observes, "depend

36. Wilde, "Lord Arthur Savile's Crime," 12.

37. Wilde, The Importance of Being Earnest, 493.

38. Ibid., 528.

39. Wilde, Soul of Man under Socialism, 36, 14.

40. Wilde, "Critic as Artist," 278. 
on a careful calculation of ways and means, always know where they are going, and go there. They start with the ideal of being the parish beadle, and ... succeed in being the parish beadle and no more" (Epistola, 216). Far from seeing this as a realization of autonomy, Wilde views it as a failure to realize all of their possible lives: "A man whose desire is to be something separate from himself, to be a member of Parliament, or a successful grocer, or a prominent solicitor . . . invariably succeeds in being what he wants to be. That is his punishment. Those who want a mask have to wear it" (Epistola, 216). ${ }^{41}$ Wilde's examples of "masks" are all professions; he is precisely worried about the limitations of an agency based on setting a vocational goal and tailoring one's activities to realize it. Accordingly, Pater like Wilde rejects the ideals of goal setting. Instead, the ideal agent will need to accept the fact of endless alteration: "He will realize himself in many forms ... through constant change, and through constant change alone, he will find his true unity." 42

What does this mean? How can constant change produce unity? For Pater, the answer depended on the capacity for disinterested experience, but Wilde is skeptical of this answer, which he believes to be both practically impossible and morally troubling. ${ }^{43}$ In place of Pater's disinterested aesthetic self, Wilde offers something strange and in need of explanation-the self

41. It is unclear how one should regard the relationship between "Epistola" and Wilde's previous work: whether it is a natural extension from the rest of his writing and compatible with the rest of his oeuvre, or whether its distinctive features (e.g., the emphasis on Christ) mean it should be understood as a significant break with the earlier Wilde. For instance, for an argument that the letter's structure is determined by the fact that Wilde was writing from prison, see Regenia Gagnier, "De Profundis as Epistola: In Carcere et Vinculis: A Materialist Reading of Oscar Wilde's Autobiography," Criticism 26, no. 4 (Fall 1984): 335-54. Not least, the text itself deals with these issues: Wilde describes errors in his previous views as much as he castigates Douglas over the course of the letter. But I will suggest here that in the final analysis the letter is the fullest and most sophisticated elaboration of the philosophical position Wilde had been developing over the course of his career. Admittedly my interpretation runs the risk of accepting what Quentin Skinner calls "the mythology of coherence": the idea that any particular piece of writing fits in naturally with everything else a thinker wrote ("Meaning and Understanding in the History of Ideas," History and Theory 8, no. 1 [1969]: 16). A full defense of this method is impossible here, although I attempt one in "Justifying Anachronism," chap. 3 of my forthcoming book The Ideas in Stories. In this essay I limit myself to trying to show many seemingly difficult elements of "Epistola"-Jesus Christ in particular - in fact fit naturally with Wilde's previous thought.

42. Wilde, "Critic as Artist," 284.

43. The two writers famously discussed each other's novels, so we have an unusually clear sense of the debate. Thus, Wilde claims, "Pater seeks to reconcile the artistic life with the life of religion, in the deep, sweet, and austere sense of the word. But Marius is little more than a spectator" (Epistola, 204). And for his part, Pater claims that Wilde failed to recognize the importance of the "moral sense," which contributes to an event's beauty or ugliness (Walter Pater, Sketches and Reviews [New York: Boni \& Liveright, 1919], 128). 
as an aesthetic faculty that is itself a work of art. "Epistola" introduces this idea in the notion of a "character": "I took pleasure where it pleased me, and passed on. I forgot that every little action of the common day makes or unmakes character . . I ceased to be lord over myself. I was no longer the captain of my soul, and did not know it" (Epistola, 194-95). For Wilde, at this stage of his thought anyway, every desire one acts on is like a mark on oneself, and ideal agency involves recognizing and responding to this fact. And this idea is not unique to Wilde's final essay, for the notion of the self as work of art crops up as well in Dorian Gray, when Lord Henry Wotton tells Dorian in the final pages of the 1891 novel The Picture of Dorian Gray that "Life has been your art." ${ }^{44}$ What is ironic is precisely how true this is, since Dorian has produced a work of art with his life. It is simply not the one realized in his body, but the picture in his attic that bears the marks on his character.

We see here Wilde dealing with a difficult and durable philosophical problem. Is it possible to conceive of the unity of the self in such a way that unity doesn't depend on a hierarchy of desires and goals, positing some as more essential and thus foundational? A half century later, one finds JeanPaul Sartre returning to the same issue, and similarly thinking that the work of art offers an important analogue for this kind of self-unification. At one point in his 1946 essay "Existentialism Is a Humanism," Sartre tries to explain how his theory of agency does not require him to hold that freedom is simply caprice - acting on the basis of a desire for no particular reason. At the same time, he explicitly rejects the idea of a motivational essence to the self, whether discovered or created. No matter how firmly an agent identifies with a particular desire, that desire is no more or less essential to the self than any other. In balancing the claim that freedom does not require agents to select desires to act on randomly with the claim that there can be no essential personal nature offering criteria for deciding which desires really reflect oneself, Sartre turns to art.

"Let us say," he opens, "that the moral choice is comparable to the construction of a work of art":

Does anyone reproach an artist, when he paints a picture, for not following rules established a priori. Does one ever ask what is the picture that he ought to paint? As everyone knows, there is no predefined picture for him to make; the artist applies himself to the composition of a picture, and the picture that ought to be made is precisely that which he will have made. As everyone knows, there are no aesthetic values a priori, but there are values which will appear in due course in the coherence of the picture, in the relation between 
the will to create and the finished work. No one can tell what the painting of tomorrow will be like; one cannot judge a painting until it is done. What has that to do with morality? We are in the same creative situation. ${ }^{45}$

Sartre's metaphor is revealing. The self is not the realization of a pregiven idea; the artist does not follow an intentional, planned scheme. Rather, the form that will give "coherence" to the painting emerges over the course of the painting being created. Each stroke of paint is not placed randomly in relation to the other strokes of painting, but the pattern that makes each new stroke not random emerges from the other strokes of paint on the canvas: the values that determine the form appear from the painting in process. Yet this is not the process of self-constitution through the hierarchy of desires the neo-Hegelians have in mind. For one thing, as Sartre stresses, "one cannot judge a painting until it's done."

Wilde is struck by this way of thinking about norms, as shifting from a way of assessing actions to a way of assessing character. As he puts it, "I see that there is nothing wrong in what one does. I see that there is something wrong in what one becomes" (Epistola, 196). The ethical failing depends on what one does to oneself - on how it mars the work of art one is making with one's life. But what determines the form of that work must also come from oneself. "Only that is spiritual which makes its own form" (Epistola, 197). As with Picasso's painting, the fact that there are no preexisting values does not mean mistakes are impossible. The painting can give itself a structure as it emerges, and it is possible for new brushstrokes to jar with it.

This way of thinking about the self gives rise to the center of the essay, Wilde's radical rereading of the life of Jesus Christ, who is for him "just like a work of art." Counterintuitively, Wilde claims "to live for others as a definite self-conscious aim was not [Christ's] creed" (Epistola, 208). Instead, Christ is the "supreme individualist," living only to be himself. Wilde refuses the governing assumption of the Gospel of Work that working selflessly is the best way to realize one's self; in place of this axiom, he offers the view that it is aesthetic self-regard that enables autonomy. Christ realizes an artistic pattern he has given himself: "He made of himself the image of the Man of Sorrows, and as such has fascinated and dominated art" (Epistola, 209). Nor did he borrow the form. "The strange figures of poetic drama," Wilde contends, "are made by the imagination of others, but out of his own imagination entirely did Jesus of Nazareth create himself" (Epistola, 211). The artistic structure of Christ's life, which so successfully realized

45. Jean-Paul Sartre, "Existentialism Is a Humanism," in Basic Writings of Existentialism, ed. Gordon Marino (New York: Modern Library, 2004), 361. 
the aesthetic ideal of suffering that it dominated subsequent art, was not preestablished but was given by himself to himself. And the importance of giving one's life such a structure, more than anything, is what we should take from Christ's example: "Every human being should be the realization of some ideal" (Epistola, 210). ${ }^{46}$

Such a view has the attractive aspect that it is compatible with at least some versions of determinism. Clearly the determinist thesis worried Wilde. As Lord Henry Wotton explains the problem, "Life is not governed by will or intention. Life is a question of nerves and fibers, and slowly built up cells in which thought hides itself and passion has its dreams." ${ }^{47}$ The traditional response to this problem is to say that freedom of the will does not require indeterminacy; rather, as Bradley and many others would say, freedom requires simply autonomy, that the causes of one's actions be internal to oneself. So it is not threatening to freedom if an action is determined, so long as its cause is part of one's self. But Wilde, precisely because he has abandoned the basic structure of the professional theory of agency, does not have access to this line of thought. It is not immediately obvious, then, how to see someone like Dorian Gray as self-controlled. We might note, however, one thing that Dorian does control- how to interpret and understand the causes of his actions. ${ }^{48}$

David Velleman's theory of the self touches on this point. For him, the self is simply the reflexive stance, the name for the perspective from which I look at myself in the mirror. In so doing, I may not be able to control the causes of my actions, but I can make sense of them after I have done them. He explains: “Thus, for example, one's being interested in jazz would explain why one might frequent nightclubs, and so one can frequent

46. This is an extension of and a slight disagreement with the subtle reading of "Epistola" Julia Prewitt Brown offers. I concur with her suggestion that Wilde's goal here is to incorporate all experiences into a whole: she writes that even the most "difficult, harmful, and questionable of experiences do not detract from but complete the whole" ( Julia Prewitt Brown, Cosmopolitan Criticism: Oscar Wilde's Philosophy of Art [Charlottesville: University Press of Virginia, 1997], 103). But her suggestion for how to do this involves a Nietzschean love of one's fate and a willing of the eternal return; to my mind, this misses the thrust of the aesthetic vocabulary, and the way the "whole" Wilde seeks to achieve is very much the aesthetic whole of a narrative.

47. Wilde, Picture of Dorian Gray, 178-79. In "Oscar Wilde and the Freedom of the Will," a compelling essay currently in manuscript, Andrea Selleri has unpacked Wilde's fascination with the problem of the freedom of the will and the complexity of causality in The Picture of Dorian Gray.

48. Elisha Cohn has argued recently that Wilde's aestheticism was a response to his materialism, deflating traditional emphasis on autonomous subjectivity and reframing "recalcitrant materiality as a pleasure rather than a problem” (“'One Single Ivory Cell': Oscar Wilde and the Brain," Journal of Victorian Culture 17, no. 2 [June 2012]: 205). But this leaves the notion of autonomy behind too quickly and misses Wilde's philosophical creativity in reinventing a theory of freedom. 
nightclubs not only out of an interest in jazz but also on the grounds of that interest, regarded as explanatory of one's behavior. When one's behavior is guided by such considerations, it is guided by one's capacity for making sense of behavior, which is one's causal understanding and is therefore presented in reflexive guise to that very understanding, as the self that causes one's behavior." ${ }^{49}$ Velleman's point here is a subtle one. He is claiming that one can look back at the causes of one's actions and see how they make sense. If I find myself constantly listening to jazz, perhaps that is because I am interested in jazz. But upon that realization, I subsequently construct a self-conception, one based on my ability to make sense of behavior. And it turns out that that self-conception-believing that this is the kind of thing I do- has an effect on my subsequent behavior. Drawing on research in social psychology, Velleman argues that making a prediction about what we will do makes us more likely to do that thing; similarly, what we represent to ourselves as feeling affects what we do in fact feel. Tellingly for Oscar Wilde, Velleman calls this capacity of the self - our capacity to understand causal behavior, and for that understanding of ourselves to affect subsequent action-the self as "narrator." 50

So if we do not entirely control the actions that we perform, we do control the narrative that we write about them. And that narrative can influence our subsequent actions. This distinction captures, it seems to me, the mix of truth and self-deception in Dorian Gray's belief that he is helpless in the face of biological law. Perhaps many of his actions are indeed determined, but his belief in that determinism is a contributing factor. Moreover, his greatest moral failure lies in his refusal to recognize the real work of art he is making with his life. In other words, this way of thinking about a self-conception aestheticizes it, since the narrative one tells about one's life is part of the work of art that one's self is.

That's the philosophical intuition behind the striking emphasis on forgiveness in Wilde's "Epistola." In his words:

Of course the sinner must repent. But why? Simply because otherwise he would be unable to realize what he had done. The moment of repentance is the moment of initiation. More than that: it is the means by which one alters one's past. The Greeks thought that impossible. They often say in their Gnomic aphorisms, "Even the Gods cannot alter the past." Christ showed that the commonest sinner could do it, that it was the one thing he could do. Christ, had he been asked, would have said-I feel quite certain about it - that the moment the prodigal son fell on his knees and wept, he made his having wasted his

49. David Velleman, Self to Self: Selected Essays (New York: Cambridge University Press, 2006), 8.

50. Ibid., 214-15. 
substance with harlots, his swine-herding and hungering for the husks they ate, beautiful and holy moments in his life. It is difficult for most people to grasp the idea. I dare say one has to go to prison to understand it. If so, it may be worth while going to prison. (Epistola, 215)

The events in the past have not literally changed, but what does change is what they mean. By the act of repentance, they become beautiful. ${ }^{51}$ That beauty stems from their incorporation into a narrative. Repentance, as an act, transforms the sins committed from ordinary evils into necessary elements in a story. Agents may not be able to stop themselves from committing the sins in the first place, but "the one thing" they can do is control the attitude they take toward them, the story they fit into-and thus the actions change from wayward moments of heteronomy into the coherence of autonomy. It is the fact of the importance of this aesthetic control that Wilde emphasizes in the last few sentences. Even though he is imprisoned, he still controls the story of his life. And in that sense, prison has not impaired him at all.

Let's turn now to William Morris, who had a much different take on the relationship between art and labor, and work our way back to a comparison between him and Wilde. At the center of Morris's thought was the essentially Marxist argument (though how much Marx he knew is a matter of some debate) that the division of labor characteristic of industrial capitalism created only degraded forms of labor, which made it impossible to realize the actual benefits work could offer. ${ }^{52}$ These arguments emerge most clearly in his 1888 essay "Useful Work versus Useless Toil," where Morris, in agreement with Wilde, opens by denying the Carlylean position that all work is good for its own sake. ${ }^{53}$ But their agreement stops here. For Morris, work can indeed be a blessing when it has "hope in it," a criterion that in his view has three dimensions - "hope of rest, hope of product, hope of pleasure in the work itself" (UW, 604). None of these conditions

51. Regenia Gagnier argues that the letter alternates between two opposed stylistic modes - "realism and romance" - as a way of resisting the life imposed by the prison system (Idylls of the Marketplace: Oscar Wilde and the Victorian Public [Stanford University Press, 1986], 192). One way of glossing my argument here is to say that the latter is the best means of creating autonomous agency in the former.

52. For a discussion of the alternate interpretations of Morris's intellectual history, see Carolyn Lesjak, Working Fictions: A Genealogy of the Victorian Novel (Durham, NC: Duke University Press, 2006), 158.

53. William Morris, "Useful Work versus Useless Toil," in Stories in Prose, Stories in Verse, Shorter Poems, Lectures and Essays, ed. G. D. H. Cole (London: Nonesuch Press, 1948), 603. Further citations are marked UW and included parenthetically in the text. 
were being met by the kind of work available in late nineteenth-century England. There is no rest, because workers are driven by financial need to work too hard and too long (UW, 610). There is no useful product, because most of the goods that are made are poorly or badly constructed and answer only artificial needs and desires (UW, 621). But finally, there is no hope of pleasure in work, which is ultimately the central challenge: "Nature will not be finally conquered till our work becomes a part of the pleasure of our lives" (UW, 611). As Carolyn Lesjak puts it, Morris thus points to "a fundamentally different everyday relationship to labor, one radically opposed to the organization of labor in the processes of capitalist production." 54 Instead of a sharp division between work and leisure or relaxation, Morris's ideal state involves a combining of the two so that work becomes a form of pleasure in itself.

What makes work pleasurable? There are four criteria and a proviso. Work should be made attractive "by the consciousness of usefulness, by its being carried out with intelligent interest, by variety, and by its being carried out amidst pleasurable surroundings," and there is a governing condition "that the day's work should not be wearisomely long" (UW, 619). The differences between these criteria are as intriguing as their combination: usefulness seems to be a social criterion, reflecting the needs of others beyond the self. In this it gestures, albeit in a much-condensed fashion, at the neo-Hegelian idea that true autonomy requires an interaction between social structure and individual agency. And Morris echoes an idealist theme in making "independent interest" a criterion; Bradley would agree that the worker must be able to regard the work as intrinsically valuable. But the three additional components, and particularly the third criterion's emphasis on variety, incorporate aestheticist ideas. Morris writes that craftsmen often almost instinctively ornament their products out of a simple attempt to enjoy working: "The origin of this art was the necessity that the workman felt for variety in his work." Borrowing a thought from John Ruskin, he argues that the presence of ornamentation demonstrates the worker's success. "The obtaining variety and pleasure in the work by the workman . . stamped all labor with the impress of pleasure" (UW, 617).$^{55}$

54. Lesjak, Working Fictions, 144.

55. This is an idea Morris borrows more or less directly from John Ruskin. In the famous chapter "The Nature of Gothic" in The Stones of Venice, Ruskin writes that the presence of such variety is a constitutive feature of Gothic art. Far from the geometric standardization of Greek art, Gothic art is marked by its "ugly goblins, and formless monsters, and stern statues, anatomiless and rigid," but these are not artistic failures: "they are the signs of the life and liberty of every workman who struck the stone" (John Ruskin, The Stones of Venice, vol. 2 [London, 1867], 163). Also deeply suspicious of industrial capitalism, Ruskin writes that to let a worker be present in his work as a person - as a thoughtful moral agent - is necessarily to accept the possibility of such variation in the product (161). 
The fact that the worker is present as a person in the act of working appears in the idiosyncratic qualities of the ornamentation he applies to the object, and it is the possibility of using his intelligence and varying his work in this way that makes it pleasurable. So art is indeed essential to human autonomy, but finds its true role as an accompaniment to useful work, not as an alternative.

The interaction of these various criteria forms one of the more interesting elements in the society described in Morris's 1890 Utopian novel News from Nowhere. The novel imagines life several generations after a successful socialist revolution, telling the story from the perspective of one William Guest, who goes to sleep in the 1880 s and wakes up a century later. As a result of the dramatic social change, a variety of desires and correspondingly many products have disappeared. A character named Hammond, who guides Guest through the new world, explains: "We have now found out what we want, so we make no more than we want; and as we are not driven to make a vast quantity of useless things, we have time and resources to consider our pleasure in making them. ${ }^{56}$ Correspondingly, the limitation of work to only useful work has made it enjoyable - so much so that one subgroup, termed the "Obstinate refusers," decline to go to a festival because they wish to continue working. ${ }^{57}$ Hammond, echoing Morris, tells Guest that work is enjoyable "either because of the hope of gain in honor and wealth ... or else because it has grown into a pleasurable habit," or finally "because there is conscious sensuous pleasure in the work itself; it is done, that is, by artists." ${ }^{58}$ The link across the semicolon here reveals that it is constitutive of an artwork, in Morris's view, that it is created with pleasure. As Rob Breton usefully points out, we see here a gap between Morris and the Marxist tradition: "Whereas Marxism assigns a special consciousness to the proletariat, English socialism yearns to revitalize the artisan and his or her insights." 59

A striking feature of the book is its lack of a system for assessing and subsequently developing useful skills, so as to meet the need for useful work. There are no schools, much less a centralized educational system; perhaps more strikingly, there is also no cash market - Guest's attempts to pay for things form a running joke, and what markets there are show people simply taking what they need. The story's brief mentions of the question of skills distribution and formation are, perhaps unsurprisingly, vague; one moment has Hammond saying, "People found out what they were fit

56. William Morris, News from Nowhere, in Cole, Stories in Prose, 90.

57. Ibid., 162.

58. Ibid., 86 .

59. Rob Breton, "WorkPerfect: William Morris and the Gospel of Work," Utopian Studies 13, no. 1 (2002): 54 . 
for, and gave up attempting to push themselves into occupations in which they must needs fail." ${ }^{60}$ In other words, it seems as if the elimination of false needs and correspondingly false skills has made the needs of the collective more transparent, in such a way that little mediation is necessary. Certainly, that seems to be what Hammond has in mind in this passage. "The wares which we make are made because they are needed: men make for their neighbors' use as if they were making for themselves, not for a vague market of which they know nothing, and over which they have no control: as there is no buying and selling, it would be mere insanity to make goods on the chance of their being wanted; for there is no longer any one who can be compelled to buy them." ${ }^{61}$ Thus, the first test for assessing whether a product (and the skill to make it) is useful is to ask oneself whether one wants it. The fact that there are no longer false needs means that honest reflection upon oneself (one makes as if making for oneself) is all that one need do to figure which products and services are necessary; no input from the other people who actually receive the goods need be involved. ${ }^{6}$ This seems implausible, but Hammond and Morris try to make it more reasonable by comparison to a market, observing that markets are not much better as guides to what products and skills are actually useful.

A second test for assessing the usefulness of a task is equally important. Echoing an idea from "Useful Work versus Useless Toil," Hammond explains to Guest that sometimes particular goods and services have been eliminated when it turned out there was no way to produce them without oppression: "From time to time, when we have found out that some piece of work was too disagreeable or troublesome, we have given it up and done altogether without the thing produced by it." ${ }^{33}$ This suggests that Morris's criteria for pleasurable work are intriguingly interrelated; when a task fails to meet one criterion, there is a good chance that it fails the other as well. Thus, if a task cannot be performed with independent interest or in pleasant surroundings, for instance, Hammond would have us consider whether it is really useful.

But the performance of useful tasks is accompanied by an apparently widespread flexibility. There is no clear division of labor in Morris's imagined society, and characters move easily between skilled tasks over the

60. Morris, News from Nowhere, 67.

61. Ibid., 90.

62. This is to qualify a point in Carolyn Lesjak's account of Morris. She asserts, "Needs, like the notion of reasonable use, are ambiguous in that they only become meaningful in a communal context and hence are always themselves socially mediated rather than transparent, historically and culturally contingent rather than universal" (Lesjak, Working Fictions, 148). On my reading, Morris denies this last point to the extent he can: his goal is precisely to build a society around all and only universal or real needs that require no mediation.

63. Morris, News from Nowhere, 91. 
course of the book. That is to say that there are crafts - rowing and metallurgy are described among other particular practices-but not precisely craftspeople. Although Morris suggests it is likely people primarily work at one particular trade, since that trade suits their own "special turn of mind," there is no political or economic limit requiring them to focus only on that craft. Thus, while Morris's workers are flexible, that flexibility has not been commodified - it is their specific craftsmanship, not their fluidity, that allows them to create useful goods. And it is striking to compare Morris's sense that no social institutions are necessary to regulate the processes of skill cultivation with, for instance, Fredric Jameson's; in Jameson's utopia, there is a "Psychoanalytic Placement Bureau" designed to "handle and organize all forms of employment. ${ }^{64}$

So let us say that there are three theories of the self at stake here. At one end is the professional model, with its conception of a self constituted through identification with a socially valuable project that organizes one's internal chaos of inclinations into a clear hierarchy with orders of importance; at the other end is the aestheticist model in which the capacity for experience is the core of human autonomy, and where self-constitution depends not on an ordering of projects but instead on fitting the parts of oneself up like the pattern of a work of art. In the middle sits William Morris's Ruskin-inspired effort to accommodate both ends of the spectrum, insisting that the experience of social usefulness is indeed essential to happiness, but that this is incomplete unless it incorporates the flexibility and creativity of artistic expression.

Of course, this does not exhaust the possible positions one might take on the matter. For example, Talia Schaffer has persuasively demonstrated the existence of a "craft paradigm" central to women's experience and writing in the middle of the nineteenth century, which on her account was explicitly structured on the basis of nonmarket exchanges in the form of gift bazaars. ${ }^{65}$ A longer or subsequent treatment might press on this difference, considering how the skills demonstrated in such crafts compare to professional skills and correspondingly how such exchanges compared to professional markets as social structures enabling the construction of the self. And while scholarship on Victorian work has been extensive, there are particularly good reasons to return to this period in intellectual history

64. Fredric Jameson, An American Utopia:DualPower and the Universal Army (NewYork: Verso, 2016), 81. In chap. 9 of the same volume, "Utopian Theory: Work, Nonwork, and the Political Imagination," Kathi Weeks rightly points out that Jameson's view of work in utopia is much closer to that of Morris's contemporary Edward Bellamy (249).

65. See Novel Craft, 9-10, and esp. 50-57, where Schaffer explains the close and vexed relationship between the craft paradigm and Morris's "Arts and Crafts" movement. 
now, given - I will suggest - the resonances between current debates about self-fashioning and late Victorian thought. ${ }^{66}$

A number of sociologists have argued the major companies of the twentyfirst century use a new model for the ideal worker. Particularly at the highest levels of elite firms, it is no longer admirable to have diligently worked one's way through a company's hierarchy by developing and executing a concrete skill. ${ }^{67}$ Instead, firms have become flattened, with compressed and less-defined hierarchies, project-centered groups that often compete with each other, and workers who move from project to project and (correspondingly) company to company. ${ }^{68}$ This kind of firm privileges not the professional, whose disinterested and skill-based identity formed a dominant ideal for much of the twentieth century, but a different kind of identity altogether ${ }^{69}$ What becomes more important than professional skill in such corporate structures are features of the self like "creativity," "flexibility," and above all "potential." ${ }^{70}$ More salient than the specific tasks one carries out are the things one could possibly become; indeed, in such an environment it becomes a liability to be tied too narrowly to a single skill. Workers are better off conceiving of themselves as consultants, lending their insight to work on particular problems but never defined solely by them. Such a vision of the ideal worker, its advocates argue, is in fact liberating. Employees are no longer constrained by a corporate hierarchy or the endless repetition of the same task, but free to realize their potential in varying kinds of activity in dynamic situations. ${ }^{71}$ Ideally the work/leisure boundary is eliminated, and work becomes so varied and rewarding, so capable of expressing the multifaceted components of oneself-so little, that is, like ordinary "work"- that the desire to stop working disappears (NS, 471).

66. For a survey of this scholarship see Patrick Fessenbecker, "The Gospel of Work: An Annotated Bibliography," in Oxford Bibliographies in Victorian Literature, ed. Juliet John (New York: Oxford University Press, 2018), https://doi.org/10.1093/OBO/9780199799558-0145.

67. See, e.g., Richard Sennett, The Craftsman (New Haven, CT: Yale University Press, 2008), 35 .

68. Richard Sennett, The Culture of the New Capitalism (New Haven, CT: Yale University Press, 2006), 52.

69. See Harold Perkin, The Rise of Professional Society: England since 1880 (New York: Routledge, 1990), for an extensive discussion of the role of the professional identity in twentiethcentury social life.

70. See Sennett, Culture of the New Capitalism, 115; and Luc Boltanski and Eve Chiapello, The New Spirit of Capitalism, trans. Gregory Elliott (New York: Verso, 2005), 97. Further citations to the latter are marked NS and included parenthetically in the text.

71. See Sennett, Culture of the New Capitalism, 12-13. 
This theory should sound familiar: it is a version of the aestheticist theory of freedom. Indeed, Luc Boltanski and Eve Chiapello have argued for a causal link. In their account of the "New Spirit of Capitalism," capitalism has developed by assimilating its critiques $(N S, \mathrm{xv})$. Given its amoral nature, capitalism lacks the means to create nonmaterial incentives for work, and so it must draw its moral energy from the various forms of criticism directed at it; as they put it, "The spirit of capitalism cannot be generated exclusively out of its own resources. As a result, it needs its enemies . . . to find the moral supports it lacks" (NS, 27). So it is not surprising that the contemporary economy now privileges a form of selfhood originally theorized by critics of capitalism; it was precisely the incorporation of the ideas underlying the "aesthetic critique," Boltanski and Chiapello contend, that marginalized the professional and inspired the "networker," who has "given up the idea of a career" and is always ready to "switch activities in the near future" $(N S, 38,359) \cdot{ }^{72}$ If consultants are figures characteristic of the twenty-first century, they were born at the end of the nineteenth.

If it is true that the consultants and networkers of the contemporary economy represent versions of the kind of selfhood elaborated by nineteenthcentury aesthetes, then perhaps we can imagine an alternative by returning to its nineteenth-century target. The Gospel of Work has been for at least a century justly condemned as capitalist ideology, and indeed its contemporary advocates in Anglo-American political life continue the unsavory tradition of using ideas about the moral benefits of work to defend reactionary politics. ${ }^{73}$ Yet the assimilation of the aesthetic critique reveals that there is nothing intrinsically liberatory in the rejection of the professional ideal, and that it is equally possible to use aestheticist ideals of freedom to defend capitalist social structures. In that light, the idea that the expression of a concrete and socially useful skill is a form of freedom merits reconsideration, if for no other reason than as an alternative to the supposed freedom of the networker.

The assimilation of the aestheticist theory of freedom has revealed, furthermore, some of its limitations. A point that recurs in contemporary sociology is that the flexible identity has become a constant source of

72. The historical claim is obviously beyond the scope of the argument here and my expertise more generally, though I find it plausible. Boltanski and Chiapello offer a number of creative supports for it, perhaps the most distinctive of which is a close reading of French management literature that shows how management techniques slowly incorporated ideas from supposedly radical thinkers like Gilles Deleuze and Jacques Derrida.

73. For effective accounts of this history, see Kathi Weeks, The Problem with Work: Feminism, Marxism, Antiwork Politics, and Postwork Imaginaries (Durham, NC: Duke University Press, 2011); and James Livingston, No More Work: Why Full Employment Is a Bad Idea (Chapel Hill: University of North Carolina Press, 2016). The impulse behind such scholarship is perhaps best captured in Livingston's slogan "Fuck Work." 
anxiety. In the transformation of the worker from a figure endowed with a specific set of skills and a defined career in a single organization to a figure moving from project to project and from task to task, a new kind of anxiety has been created. Every time a particular project ends, workers must prove themselves again, redemonstrating their value. Such transitions threaten to turn workers into merely their capacity to be commodified; as Boltanski and Chiapello write, "If he is merely his faculty for adapting, if he isn't someone, why attach oneself to him?" Thus, there is a persistent tension "between the requirement of flexibility and the need to be someone" $(N S, 461)$. As they explain further, "The slogan that sums up the ideal of a successful life as becoming oneself - That is, changing in order to bring out and discover what one potentially was, so that one is no longer the same person while nevertheless evincing conformity to an original self-is the typical expression of this tension" (NS, 461). One cannot be adaptable so long as one is faithful to an internal core, and one cannot maintain an internal core if the only element in that core is the capacity to adapt.

This is the social correlate of a philosophical problem. It is not quite clear that Wilde and Sartre have really solved the problem of the capriciousness of freedom. If it is possible for any event, no matter how strange, to be incorporated into the work of art one makes with one's life, then the presence of a capacity for self-constitution does not seem meaningfully different from its absence, and thus the notion that it is a meaningful source for rational agency looks dubious. One might call this the problem of creativity, since if all one is turns out to be one's capacity to create, then it ultimately seems one is not much of anything at all. ${ }^{74}$ To return to David Velleman's terms, if anything I do can subsequently be explained and rationalized, then my capacity to be motivated by such explanations is a source of autonomy in only a trivial sense of the word.

It's here that Morris's version of the aesthetic critique of capitalism finds its interest. Admittedly, one might argue that Morris's version of the aesthetic critique has itself been thoroughly assimilated by capitalism, in particular his collapse of the distinction between labor and leisure. As Boltanski and Chiapello observe, "The commodification of the human was favored... by the erasure of the boundary between the spheres of self-interest and disinterestedness" (NS, 471). If everything one does is work, then potentially every element of one's life is a commodity. When there is no gap between what one does for pay and what one does for pleasure, then it becomes much more difficult to use the latter as the grounding point for a critique

74. An increasing body of scholarship has sought to call the idea of creativity as a discrete faculty into question; see, e.g., Camilla Nelson, "The Invention of Creativity: The Emergence of a Discourse," Cultural Studies Review 16, no. 2 (September 2010): 49-74. 
of the ever-expanding realm of the former. Boltanski and Chiapello continue: "If it is no longer acceptable to believe in the possibility of a more 'authentic' life at a remove from capitalism . . . then what is there to halt the process of commodification?" (NS, 471). The collapse between labor and leisure in the world of News from Nowhere might in other words be the dark core of our current dystopia. Under the sign of self-expression, commodified productive activity spreads into every sphere of life.

More locally, it seems clear that Morris's tests for the definition of useful work break down if extended too far. The level of social cooperation and political regulation required to actually eliminate useful industries when the work they create is unpleasant seems much more dramatic than News From Nowhere recognizes, especially in contrast to the reliance on individual self-analysis and action in the first test. One would like to know too how Hammond's two tests interact. For instance, is a good that can only be made through an oppressive productive process yet is genuinely useful conceivable? The answer seems to be an uncomfortable maybe. "Useless Work versus Useless Toil" at one point concedes that work of the "more repulsive kind" may be necessary, and that instead of eliminating it one should minimize its psychological impact by ensuring it is shared out to everyone and not organized into an individual's career. ${ }^{75}$

Yet these objections overlook Morris's attempt to rescue usefulness from the commodity form. His intuition that it becomes possible to detect a commodity precisely insofar as it has been standardized is key here, as the presence of individual variation in the product is evidence of the lack of determination by market forces. And the value of such variation appears most obviously in the failure of attempts to commodify it. When individuals are required to perform creativity in production, when it becomes recognized that individual variation has been imposed, its value disappears. But individual variation for its own sake and by itself in the face of the commodity form is not meaningful either. Rather, acts of agency must be given specific content by a recognition of genuine usefulness to afford pleasure and freedom. Certainly Morris might have done more to explain how we come to recognize that a particular product or service is useful, and how the requirement to produce objects and services that fit the needs of others interacts with the instinct for individual variation. But I submit that this is a more

75. Morris understandably evades the question: we cannot yet know whether such unpleasant work is in fact necessary at all, since we cannot construct a "scheme" for the society of the future without knowing "which of those materials would disappear and which endure through the evolution which is leading us to the great change" (UW, 622). The basic idea of minimizing the impact of such work by sharing it has been developed extensively in Paul Gomberg's theory of "contributive justice" in How To Make Opportunity Equal: Race and Contributive Justice (Malden, MA: Blackwell, 2007); see also Andrea Veltman, Meaningful Work (Oxford University Press, 2016). 
promising version of the artistic critique than that which the philosophical tradition ultimately developed.

Near the end of The New Spirit of Capitalism, Boltanski and Chiapello consider how the artistic critique of capitalism might be revived. Quoting Andre Gorz, they write, "'Work confers upon me the impersonal reality of an abstract social individual,' giving me 'a function impersonal in its essence' . . . without having to 'engage the whole of my person in it'" $(N S, 465)$. In one sense this is a disagreement with Morris's view; Boltanski and Chiapello are praising the idea of a sharp distinction between work and leisure, construed as a difference between the public and private spheres. But in another sense, it is an iteration of Morris's view and indeed of the Gospel of Work, insofar as it recognizes the benefits of the "impersonal reality" conveyed by socially useful work. Thus, the renewal of the artistic critique need not start from scratch. Many of the key issues - in particular the various interconnections and tensions among usefulness, pleasure, skill, and flexibility - are present already in the history of that critique. And emphasizing Morris's attempt to link usefulness and pleasure is a first step in that project. 